ISSN: 1858-4837; E-ISSN: 2598-019X

Volume 15, Nomor 1 (2020),

https://jurnal.uns.ac.id/region

DOI: 10.20961/region.v1511.23188

\title{
Kesesuaian pelayanan pergerakan pejalan kaki terhadap konsep transit oriented development (Studi kasus: kawasan Dukuh Atas, DKI Jakarta)
}

\author{
Suitability of pedestrian movement services to the concept of transit oriented \\ development (Case study: Dukuh Atas area, DKI Jakarta)
}

\author{
A S Ningrum ${ }^{1}$, W Astuti $^{1}$, dan H Mukaromah ${ }^{1}$ \\ ${ }^{1}$ Program Studi Perencanaan Wilayah dan Kota, Fakultas Teknik, Universitas Sebelas \\ Maret, Surakarta, Indonesia
}

Corresponding author's email: asetianingrm@gmail.com

\begin{abstract}
Abstrak. Salah satu tujuan pengembangan Transit Oriented Development (TOD) adalah mewujudkan lingkungan ramah pejalan kaki pada kawasan kompak yang berbasis transit. Desain kawasan TOD juga mendorong penggunaan moda transportasi umum untuk mendukung pergerakan penduduk. RTRW Provinsi DKI Jakarta 2011-2030 menetapkan Dukuh Atas sebagai kawasan TOD yang diharapkan mampu memberikan pelayanan bagi pergerakan pejalan kaki secara optimal. Penelitian ini bertujuan untuk mengetahui kesesuaian dari pelayanan pergerakan pejalan kaki terhadap konsep TOD di Kawasan Dukuh Atas. Kesesuaian pelayanan pergerakan pejalan kaki ditinjau dari komponen kawasan kompak, simpul transit, jalur pejalan kaki dan fasilitas penunjang. Metode analisis adalah kuantitatif dengan teknik analisis skoring yang menggunakan sakala Guttman. Hasil penelitian menunjukkan bahwa meskipun pelayanan pergerakan pejalan kaki di Kawasan Dukuh Atas sudah sesuai dengan konsep TOD, namun diperlukan adanya peningkatan pelayanan pada beberapa aspek guna mengoptimalkan pelayanan terhadap pejalan kaki.
\end{abstract}

Kata Kunci: Pejalan Kaki; Pelayanan Pergerakan; Simpul Transit; Transit-Oriented Development; Transportasi

Abstract. One of the goals of developing Transit-Oriented Development (TOD) is to create a pedestrian-friendly environment in a compact, transit-based area. The design of the TOD area also encourages the use of public transportation modes to support resident's movements. DKI Jakarta Provincial Spatial Plan 2011-2030 sets Dukuh Atas 
as a TOD area that is expected to be able to provide optimal pedestrian movement services. This study aims to determine the suitability of pedestrian movement services to the TOD concept in the Dukuh Atas area. Suitability of pedestrian movement services in terms of components of compact areas, transit nodes, pedestrian paths and supporting facilities. The analytical method is quantitative with a scoring analysis technique that uses the Guttman scale. The results showed that although pedestrian movement services in the Dukuh Atas area are by the TOD concept, it is necessary to improve services on several aspects to optimize services for pedestrians.

Keywords: Movement Services; Pedestrians; Transit Nodes; Transit-Oriented Development; Transportation

\section{Pendahuluan}

Konsep pengembangan kota yang berkaitan dengan sistem transit pada awalnya lahir secara bertahap, dimulai sejak awal abad 20 dan terus mengalami perubahan. Lalu pada awal tahun 1990-an, Peter Calthorpe memperkenalkan konsep Transit Oriented Development yang mendorong penggunaan transportasi umum massal dengan sistem transit pada kawasan multifungsi (guna lahan campuran) [1]. Dalam penerapannya, konsep Transit Oriented Development atau TOD mengutamakan adanya integrasi antara sistem transportasi dengan kawasan yang dimaksud agar pergerakan yang terjadi dapat terakomodasi dengan baik.

Institute for Transportation and Development Policy atau ITDP [2] menyebutkan delapan prinsip dalam transportasi perkotaan yang selaras dengan tujuan penerapan dari konsep TOD yaitu walk, cycle, connect, transit, mix, densify, compact dan shift. Terlepas dari konsep TOD, prinsip-prinsip tersebut secara umum bertujuan untuk menciptakan kawasan yang ramah bagi pejalan kaki. Kondisi tersebut kemudian dapat dinilai untuk menentukan seberapa ramah suatu lingkungan bagi pejalan kaki yang juga disebut sebagai walkability [3]. Berkaitan dengan prinsip transportasi perkotaan, Delhi Development Authority [4] menyebutkan bahwa sebuah kawasan berkonsep TOD harus mampu menyediakan moda transportasi yang aksesibel bagi pejalan kaki.

Di Indonesia, khususnya di Provinsi DKI Jakarta, konsep TOD berperan penting sebagai salah satu strategi penataan ruang berdasarkan Perda No. 1 Tahun 2012 tentang Rencana Tata Ruang Wilayah Provinsi DKI Jakarta 2011-2030. Berdasarkan dokumen tersebut, terdapat beberapa kawasan yang dicanangkan untuk dikembangkan dengan orientasi sistem transit, salah satunya adalah Kawasan Dukuh Atas [5].

Penetapan kawasan tersebut sebagai kawasan berkonsep TOD selaras dengan fungsinya sebagai pusat kegiatan primer yang mencakup pusat perkantoran, perdagangan dan jasa dengan skala nasional dan internasional yang didalamnya terdapat stasiun terpadu dan titik perpindahan beberapa moda transportasi. Fungsi tersebut menjadikan Dukuh Atas berada dalam jajaran kawasan strategis kepentingan ekonomi di Provinsi DKI Jakarta. Dengan kata lain, daya tarik kawasan tersebut terbilang cukup tinggi dan mempengaruhi tingginya pergerakan yang terjadi, baik oleh kendaraan bermotor maupun pejalan kaki. 
Seperti halnya kendaraan bermotor, pejalan kaki membutuhkan ruang untuk melakukan pergerakan yang dilengkapi dengan sarana prasarana serta fasilitas penunjangnya. Secara umum, penyediaan jalur pejalan kaki dan fasilitas penunjangnya bertujuan untuk memberikan rasa aman dan nyaman serta untuk memudahkan pergerakan penggunanya [6].

Secara umum, sebagai kawasan TOD, pengembangan Dukuh Atas diarahkan pada perwujudan integrasi kawasan antara simpul transit dengan kawasan sekitar, termasuk menciptakan lingkungan ramah pejalan kaki. Akan tetapi, belum ada penelitian yang menemukenali kesesuaian pelayanan pergerakan pejalan kaki pada kawasan tersebut. Selama ini, penelitian terkait TOD hanya menitikberatkan pada substansi keberadaan masing-masing komponen dalam suatu kawasan. Oleh sebab itu, penelitian ini dilakukan untuk mengetahui kesesuaian dari pelayanan pergerakan pejalan kaki terhadap konsep TOD di Kawasan Dukuh Atas.

\section{Metode}

Penelitan ini termasuk kedalam jenis penelitian kuantitatif yang dilakukan dengan pendekatan deduktif. Proses penyusunan penelitian dibagi kedalam dua tahapan yaitu tahapan persiapan dan tahapan penelitian. Data yang dibutuhkan dalam penelitian ini merupakan data primer yang didapatkan melalui observasi lapangan dan penyebaran kuesioner. Kawasan penelitian adalah Kawasan Dukuh Atas yang berlokasi di pusat kota Provinsi DKI Jakarta, tepatnya berada di area perbatasan antara Kota Administrasi Jakarta Selatan dan Kota Administrasi Jakarta Pusat.

Deliniasi kawasan penelitian didasarkan pada beberapa kriteria antara lain ditetapkan sebagai kawasan TOD dan pusat kegiatan primer, terletak di pusat kota dan berada dalam radius 400 meter (terhitung dari titik transit). Dengan kriteria tersebut, kemudian didapatkan kawasan penelitian dengan luas 68,5 Ha (lihat Gambar 1).

\subsection{Parameter dan indikator penelitian}

Seperti yang telah disebutkan sebelumnya, parameter dan indikator penelitian didapatkan melalui proses persilangan antara variabel dan aspek akomodasi pergerakan pejalan kaki dengan rincian sebagaimana pada Tabel 1. 


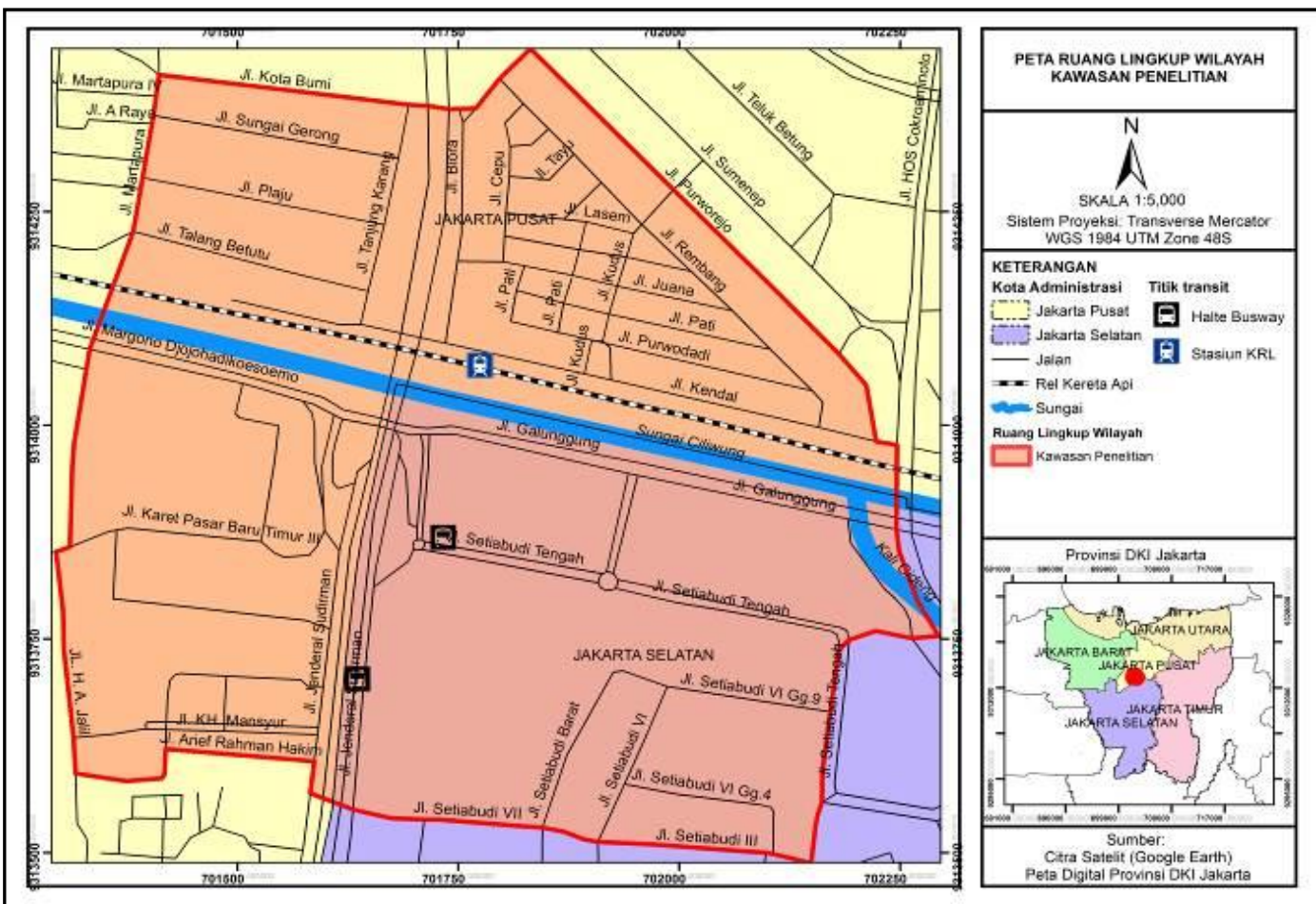

Gambar 1. Peta kawasan penelitian.

Tabel 1. Parameter dan indikator penelitian $[2,5]$.

Indikator

1. Variabel Kawasan Kompak

Kawasan campuran padat bangunan yang saling terkoneksi dengan jalur pejalan kaki

Kawasan terintegrasi dengan simpul transit

2. Variabel Simpul Transit

Simpul transit terjangkau dengan berjalan kaki

Simpul transit aksesibel bagi pejalan kaki

3. Variabel Jalur Pejalan Kaki Jalur pejalan kaki yang aman (aspek keamanan)

Jalur pejalan kaki yang nyaman (aspek kenyamanan)

Jalur pejalan kaki yang aksesibel (khususnya bagi difabel)

(aspek aksesibilitas)
Blok-blok kecil dengan jaringan pejalan kaki

Terdapat stasiun dan halte di dalam kawasan

Jarak tempuh ke simpul transit terdekat maksimal 400 meter atau 10 menit berjalan kaki

Tidak terdapat halangan pada akses masuk halte dan stasiun

Perbedaan ketinggian dengan jalur kendaraan $20 \mathrm{~cm}$ (lebih tinggi)

Penyeberangan dengan permukaan yang tidak licin Jalur pemandu yang menerus (kontinu) bagi difabel

Terdapat pagar pengaman setinggi 0,9 $\mathrm{m}$ atau jalur hijau sebagai pembatas dengan jalur kendaraan

Lebar jalur pejalan kaki $\geq 1,5 \mathrm{~m}$ (termasuk jalur penyeberangan)

Jalur dapat mengakomodasi volume pejalan kaki

Mudah dicapai dari muka blok

Tidak terhalang oleh apapun

Jalur pejalan kaki menerus

Ketersediaan ramp dengan derajat kemiringan $7 \%$ 


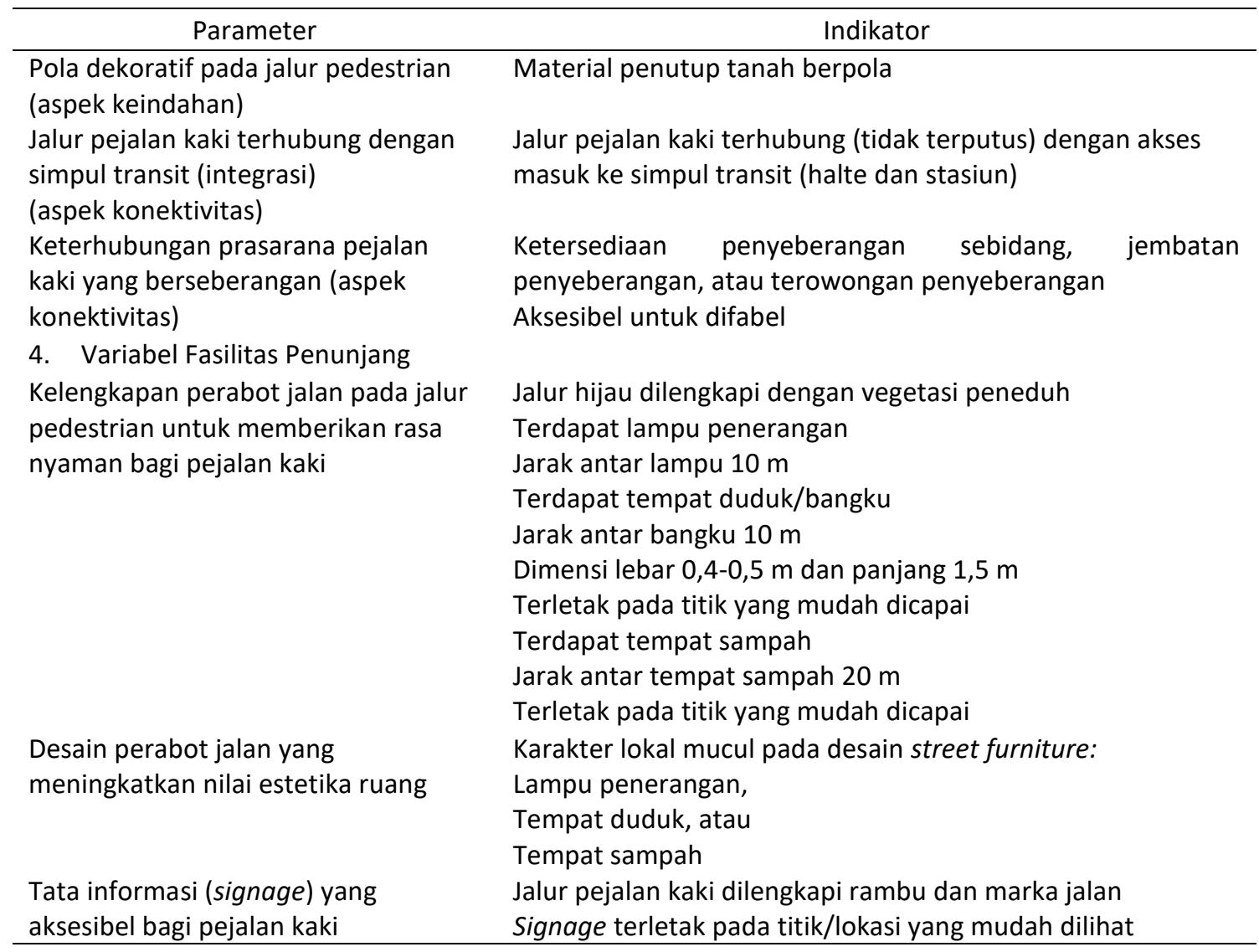

\subsection{Teknik analisis data}

Proses awal analisis pada penelitian ini dimulai dari tahap pengumpulan data dengan teknik observasi lapangan dan penyebaran kuesioner yang mengacu pada parameter kesesuaian pada tiap variabel penelitian. Tahap awal tersebut kemudian menghasilkan kondisi eksisting dari akomodasi pergerakan pejalan kaki di Kawasan Dukuh Atas. Selanjutnya, data tersebut digunakan sebagai input pada analisis skoring untuk mengidentifikasi skor kesesuaian pada masing-masing variabel penelitian. Proses terakhir yaitu analisis kesesuaian dengan input berupa skor yang telah didapatkan pada analisis skoring, menghasilkan output berupa nilai kesesuaian akomodasi pergerakan pejalan kaki terhadap konsep Transit Oriented Development di Kawasan Dukuh Atas.

Analisis skoring dilakukan dengan menggunakan Skala Guttman untuk mendapatkan nilai pada masing-masing parameter, dimana skor 1 mewakili jawaban sesuai dan skor 0 mewakili jawaban tidak sesuai. Selanjutnya, total skor yang telah didapat dikelompokkan ke dalam dua kelas kategori kesesuaian dengan rumus rentang bagai berikut.

$$
P=\frac{R}{K}=\frac{(13 \times 1)-(13 \times 0)}{2}=6,5
$$


Berdasarkan rumus di atas, berikut ini adalah rincian rentang pada masing-masing kelas dalam bentuk persentase dan skor.

- Tidak sesuai: Apabila hasil perhitungan nilai kesesuaian berada dalam rentang persentase $0-50 \%$ (skor 0-6,5), maka akomodasi pergerakan pejalan kaki di Kawasan Dukuh Atas dinilai 'tidak sesuai' dengan konsep TOD terkait

- Sesuai: Apabila hasil perhitungan nilai kesesuaian berada dalam rentang persentase 51 - 100\% (skor 6,6-13), maka akomodasi pergerakan pejalan kaki di Kawasan Dukuh Atas dinilai 'sesuai' dengan konsep TOD terkait

\section{Hasil penelitian dan pembahasan}

Pada bagian ini akan dijabarkan hasil penelitian pada masing-masing komponen TOD yaitu kawasan kompak, simpul transit, jalur pejalan kaki dan fasilitas penunjang berdasarkan masing-masing aspek penilaian.

\subsection{Kesesuaian komponen kawasan kompak terhadap konsep TOD}

Berdasarkan Tabel 1, penilaian kesesuaian pada komponen kawasan kompak ditinjau melalui bagaimana fungsi guna lahan yang beragam di Kawasan Dukuh Atas saling terkoneksi dengan adanya jalur pejalan kaki serta bagaimana integrasinya dengan simpul-simpul transit yang ada. Tabel 2 berikut ini adalah skor kesesuaian pada komponen kawasan kompak.

Tabel 2. Skor kesesuaian komponen kawasan kompak.

\begin{tabular}{|c|c|c|c|c|}
\hline \multirow{2}{*}{ Parameter } & \multicolumn{2}{|c|}{ Indikator } & \multicolumn{2}{|c|}{ Skor } \\
\hline & Sesuai & Tidak Sesuai & Sesuai & Tidak Sesuai \\
\hline $\begin{array}{l}\text { Kawasan campuran padat } \\
\text { bangunan saling } \\
\text { terkoneksi dengan jalur } \\
\text { pejalan kaki }\end{array}$ & $\begin{array}{l}\text { Terdapat jaringan } \\
\text { pejalan kaki yang } \\
\text { menghubungkan } \\
\text { blok-blok kecil }\end{array}$ & $\begin{array}{l}\text { Jaringan pejalan kaki } \\
\text { tidak } \\
\text { menghubungkan } \\
\text { seluruh blok }\end{array}$ & 1 & 0 \\
\hline $\begin{array}{l}\text { Kawasan terintegrasi } \\
\text { dengan simpul transit }\end{array}$ & $\begin{array}{l}\text { Terdapat simpul } \\
\text { transit di dalam } \\
\text { kawasan }\end{array}$ & $\begin{array}{l}\text { Tidak terdapat simpul } \\
\text { transit di dalam } \\
\text { kawasan }\end{array}$ & 1 & 0 \\
\hline
\end{tabular}

Keterangan: $1 / 0$ = skor yang diperoleh

Tabel 2 menunjukkan bahwa fungsi guna lahan campuran di Kawasan Dukuh Atas saling terkoneksi dengan keberadaan jaringan pejalan kaki yang menghubungkan blok-blok kecil di dalam kawasan (lihat Gambar 2).

Dengan jaringan pejalan kaki yang menghubungkan antar fungsi guna lahan, pergerakan pejalan kaki di Kawasan Dukuh Atas sebagai kawasan TOD dapat terakomodasi. Hal ini sesuai dengan prinsip transportasi perkotaan yang mendorong densifikasi dan efisiensi penggunaan lahan agar dapat mempersingkat jarak kebutuhan perjalanan di dalam kawasan serta membangun lingkungan yang ramah bagi pejalan kaki [2]. 


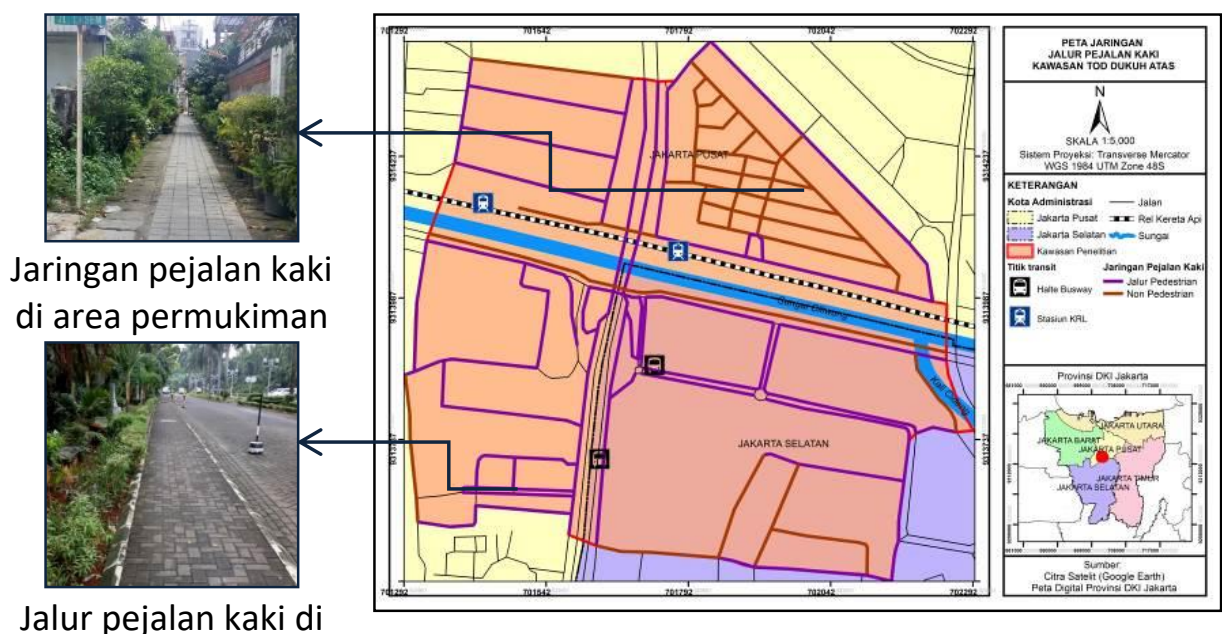
area perkantoran

Gambar 2. Peta jaringan jalur pejalan kaki.

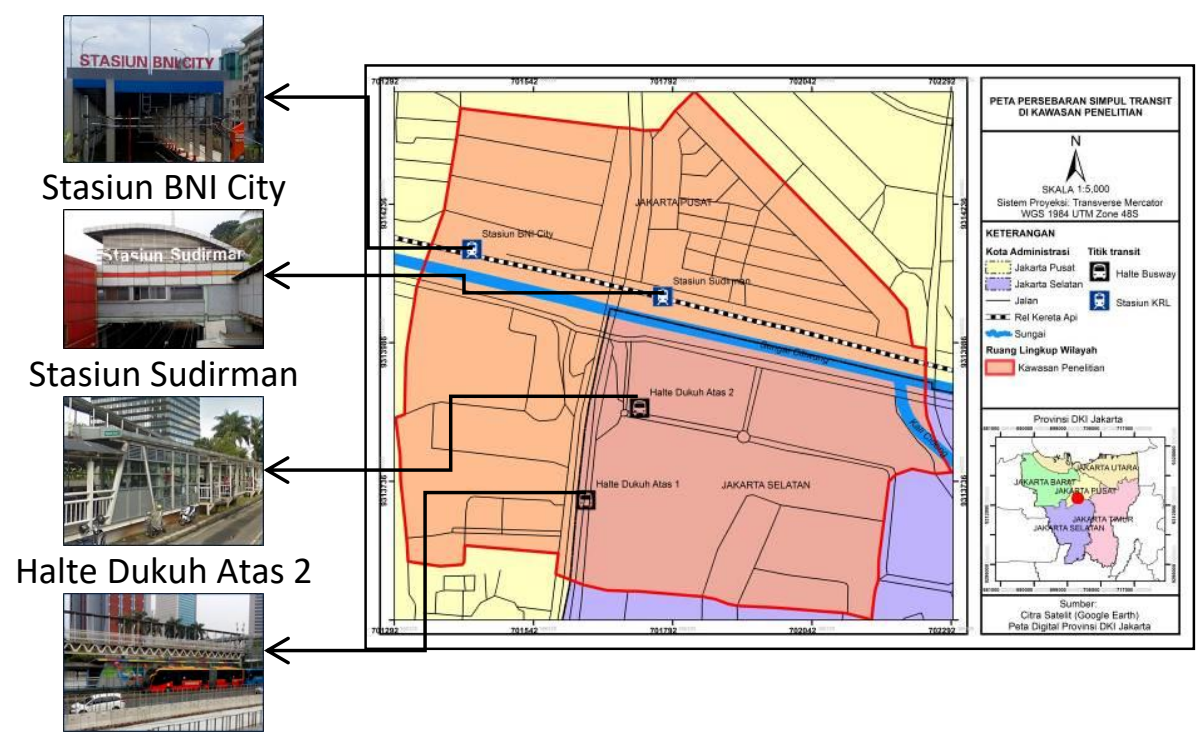

Halte Dukuh Atas 1

Gambar 3. Peta persebaran simpul transit.

Selain itu, Tabel 2 juga menunjukkan bahwa kawasan penelitian terintegrasi dengan beberapa simpul transit multi-moda berupa Stasiun Sudirman, Stasiun BNI City serta Halte Bus Transjakarta Dukuh Atas 1 dan 2 (lihat Gambar 3). Keberadaan simpul-simpul transit multimoda di Kawasan Dukuh Atas sesuai dengan ketentuan penyediaan sarana prasarana yang dikhususkan bagi pejalan kaki di kawasan TOD pada Permen PU No.3/PRT/M/2014 yang menyatakan bahwa kawasan harus terintegrasi dengan tempat pergantian moda transportasi umum [7]. 


\subsection{Kesesuaian komponen simpul transit terhadap konsep TOD}

Penilaian kesesuaian pada komponen simpul transit ditinjau melalui bagaimana keterjangkauan dan aksesibilitasnya bagi pejalan kaki. Berikut ini adalah tabel skor kesesuaian pada komponen simpul transit.

Tabel 3. Skor kesesuaian komponen simpul transit.

\begin{tabular}{|c|c|c|c|c|}
\hline \multirow{2}{*}{ Parameter } & \multicolumn{2}{|c|}{ Indikator } & \multicolumn{2}{|c|}{ Skor } \\
\hline & Sesuai & Tidak Sesuai & Sesuai & Tidak Sesuai \\
\hline $\begin{array}{l}\text { Simpul transit } \\
\text { terjangkau } \\
\text { dengan } \\
\text { berjalan kaki }\end{array}$ & $\begin{array}{l}\text { Jarak tempuh ke simpul } \\
\text { transit terdekat } \leq 400 \mathrm{~m} \\
\text { atau } \leq 10 \text { menit berjalan } \\
\text { kaki }\end{array}$ & $\begin{array}{l}\text { Jarak tempuh ke simpul } \\
\text { transit terdekat }>400 \mathrm{~m} \\
\text { atau }>10 \text { menit berjalan } \\
\text { kaki }\end{array}$ & 1 & 0 \\
\hline $\begin{array}{l}\text { Simpul transit } \\
\text { aksesibel bagi } \\
\text { pejalan kaki }\end{array}$ & $\begin{array}{l}\text { Tidak terdapat halangan } \\
\text { pada akses masuk halte } \\
\text { dan stasiun }\end{array}$ & $\begin{array}{l}\text { Akses masuk halte dan } \\
\text { stasiun terhalang sesuatu }\end{array}$ & 1 & 0 \\
\hline
\end{tabular}

Keterangan: $1 / 0$ = skor yang diperoleh

Pada Tabel 3, diketahui bahwa simpul transit di Kawasan Dukuh Atas dinilai terjangkau oleh pejalan kaki dengan jarak tempuh maksimal 400 meter atau waktu tempuh 10 menit dari dan ke kawasan sekitarnya. Hal ini sesuai dengan Permen PU No.3/PRT/M/2014 [7] pada bagian pengembangan kawasan transit.

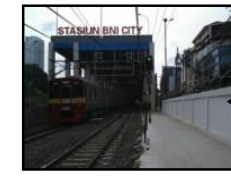

Akses masuk stasiun dari jalur pedestrian Jalan Sudirman

Akses masuk pejalan kaki dari Stasiun Sudirman

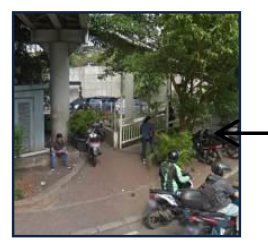

Akses masuk pejalan kaki dari jalur pedestrian Jalan Setiabudi Tengah

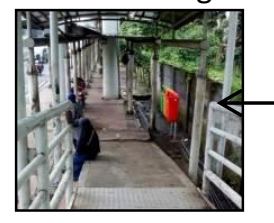

Akses masuk pejalan kaki dari jalur pedestrian Jalan Sudirman

Gambar 4. Kondisi eksisting akses masuk simpul transit.

Selain itu, ditemukan pula bahwa masing-masing simpul transit di Kawasan Dukuh Atas aksesibel bagi pejalan kaki dengan tidak ditemukannya halangan pada akses masuk halte dan stasiun (lihat Gambar 4). Dengan begitu, pejalan kaki yang juga merupakan pengguna 
transportasi umum dapat melakukan pergerakan dengan mudah. Berdasarkan hal tersebut, komponen simpul transit di Kawasan Dukuh Atas memenuhi kriteria pada standar penilaian dalam TOD Standard [2].

\subsection{Kesesuaian komponen jalur pejalan kaki terhadap konsep TOD}

Berikut ini adalah penjabaran hasil penelitian pada masing-masing aspek yang termasuk dalam komponen jalur pejalan kaki yaitu aspek keamanan, kenyamanan, aksesibilitas, keindahan dan konektivitas jalur.

3.3.1 Aspek keamanan jalur pejalan kaki. Penilaian aspek keamanan pada jalur pejalan kaki di Kawasan Dukuh Atas ditinjau melalui empat kriteria diantaranya adalah perbedaan ketinggian jalur, kondisi permukaan jalan pada jalur penyeberangan, kontinuitas jalur pemandu dan ketersediaan pagar pengaman atau jalur hijau sebagai pembatas dengan jalur kendaraan. Berikut ini adalah tabel skor kesesuaian pada aspek keamanan.

Tabel 4. Skor kesesuaian aspek keamanan jalur pejalan kaki di kawasan Dukuh Atas.

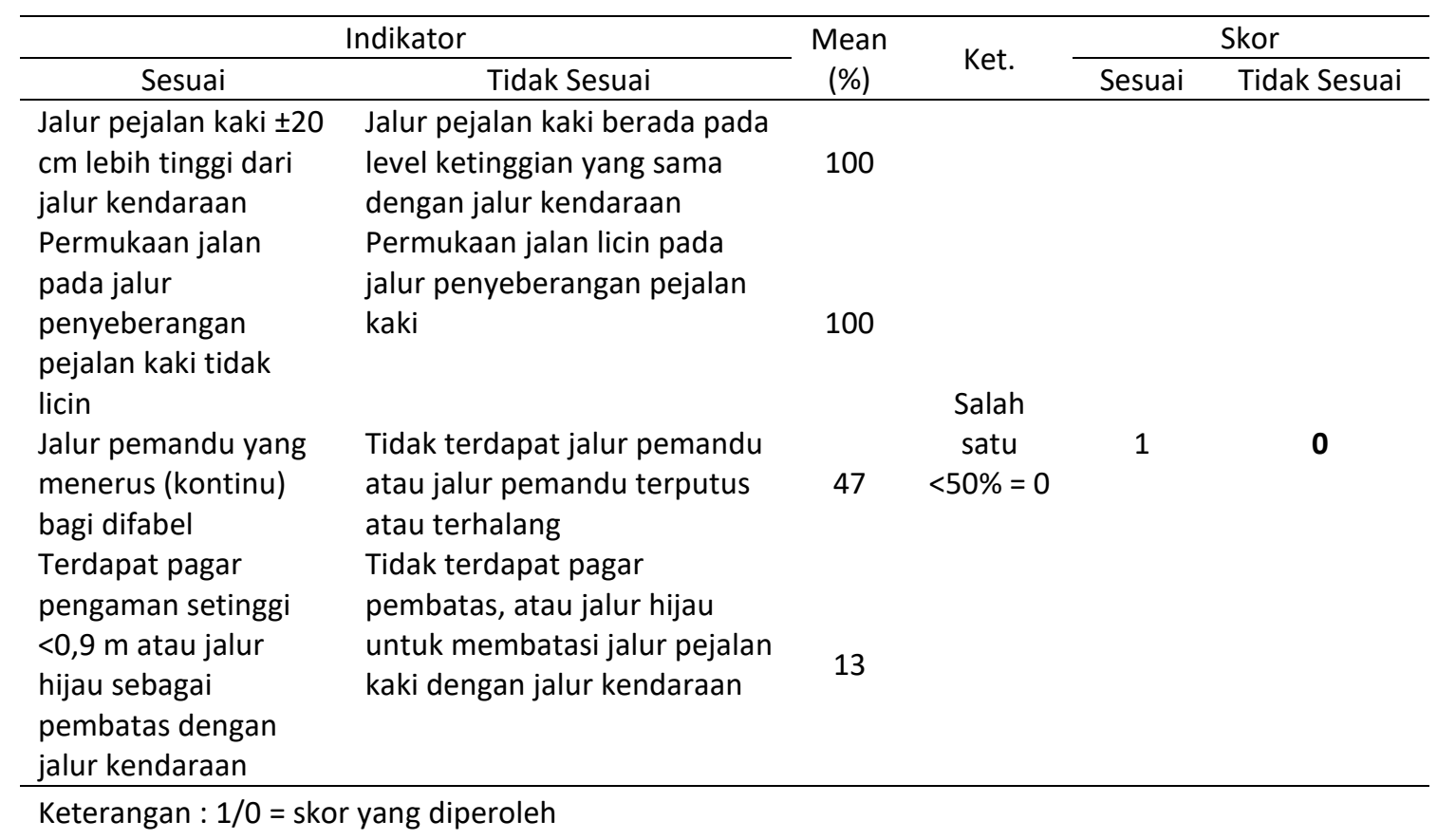

Berdasarkan Tabel 4, diketahui bahwa seluruh jalur pejalan kaki di Kawasan Dukuh Atas berada pada level ketinggian yang berbeda dengan jalur kendaraan sehingga dapat mengurangi risiko konflik dengan kendaraan bermotor. Selain itu, permukaan jalan pada seluruh jalur penyeberangan dinilai tidak licin dan aman bagi pejalan kaki (lihat Gambar 5). 


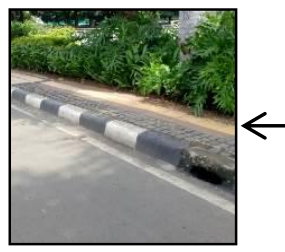

Jalur pedestrian lebih tinggi dari jalur kendaraan

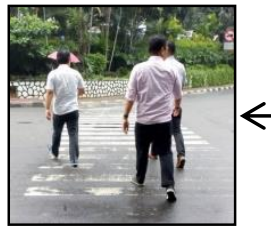

Permukaan jalan pada jalur penyeberangan tidak licin

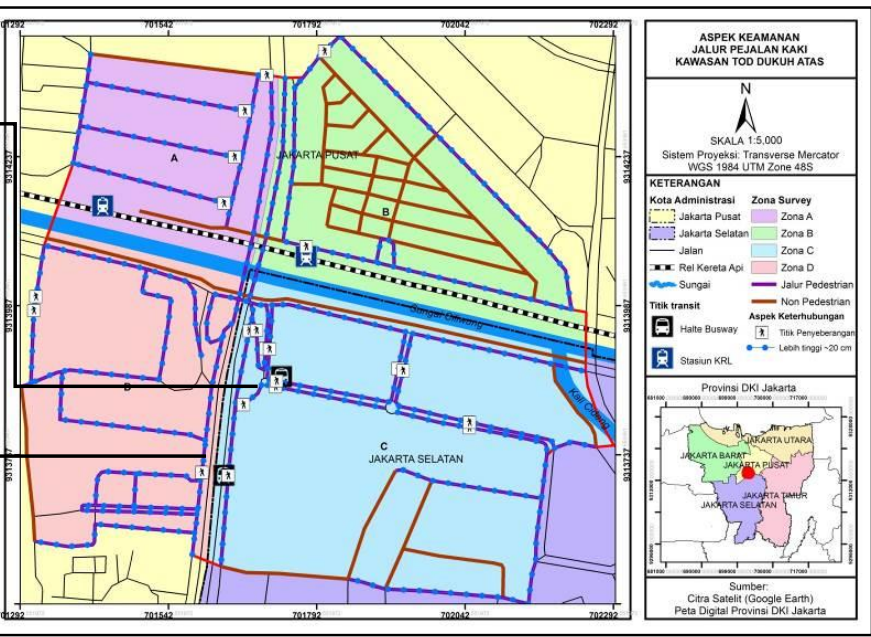

Gambar 5. Aspek keamanan jalur pejalan kaki di kawasan TOD Dukuh Atas (Bagian 1).

Selanjutnya, pada Tabel 4 ditemukan pula bahwa jalur pemandu untuk difabel tidak bersifat kontinu dan jalur hijau sebagai pembatas tidak tersedia di sepanjang jalur pedestrian di Kawasan Dukuh Atas (lihat Gambar 6).

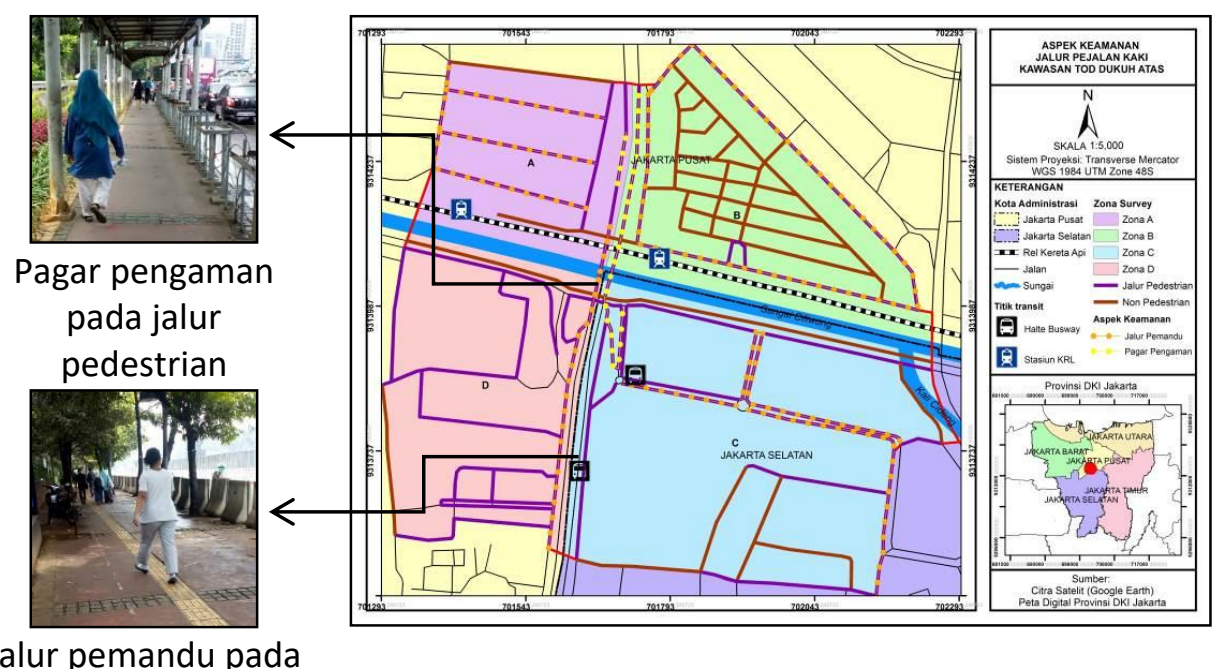

Jalur pemandu pada

jalur pedestrrian

Gambar 6. Aspek keamanan jalur pejalan kaki di kawasan TOD Dukuh Atas (Bagian 2).

Menurut hasil analisis di atas, jalur pejalan kaki di kawasan Dukuh Atas dinyatakan tidak sesuai dengan konsep TOD dalam mengakomodasi pergerakan dengan memberikan rasa aman bagi penggunanya yang merupakan salah satu prinsip penyediaan jalur pedestrian oleh Tumlin dalam Mauliani et al [6].

3.3.2 Aspek kenyamanan jalur pejalan kaki. Pada penelitian ini, aspek kenyamanan pada jalur pejalan kaki di Kawasan Dukuh Atas dilihat dari lebar eksisting jalur dan kemampuan jalur 
tersebut dalam mengakomodasi volume pejalan kaki yang terjadi. Berikut ini adalah tabel skor kesesuaian pada aspek kenyamanan.

Tabel 5. Skor kesesuaian aspek kenyamanan jalur pejalan kaki di kawasan Dukuh Atas.

\begin{tabular}{|c|c|c|c|c|c|}
\hline \multicolumn{2}{|c|}{ Indikator } & \multirow{2}{*}{$\begin{array}{c}\text { Mean } \\
(\%)\end{array}$} & \multirow{2}{*}{ Ket. } & \multicolumn{2}{|c|}{ Skor } \\
\hline Sesuai & Tidak Sesuai & & & Sesuai & Tidak Sesuai \\
\hline $\begin{array}{l}\text { Lebar jalur pejalan } \\
\text { kaki } \geq 1,5 \mathrm{~m} \\
\text { (termasuk jalur } \\
\text { penyeberangan) } \\
\text { Jalur dapat } \\
\text { mengakomodasi } \\
\text { volume pejalan kaki }\end{array}$ & $\begin{array}{l}\text { Lebar jalur pejalan } \\
\text { kaki (termasuk jalur } \\
\text { penyeberangan) }<1,5 \\
\mathrm{~m} \\
\text { Jalur tidak dapat } \\
\text { menampung volume } \\
\text { pejalan kaki }\end{array}$ & 100 & $\begin{array}{l}\text { Salah satu } \\
<50 \%=0\end{array}$ & 1 & 0 \\
\hline
\end{tabular}

Berdasarkan Tabel 5 di atas, diketahui bahwa lebih dari separuh jalur pejalan kaki di Kawasan Dukuh Atas memiliki lebar sesuai standar yaitu $\geq 1,5$ meter menurut Permen PU No.3/PRT/M/2014 [7] (lihat Gambar 7). Selain itu, ditemukan pula bahwa lebar eksisting dari jalur pejalan kaki di Kawasan Dukuh Atas telah mampu mengakomodasi volume pejalan kaki yang melewati kawasan.

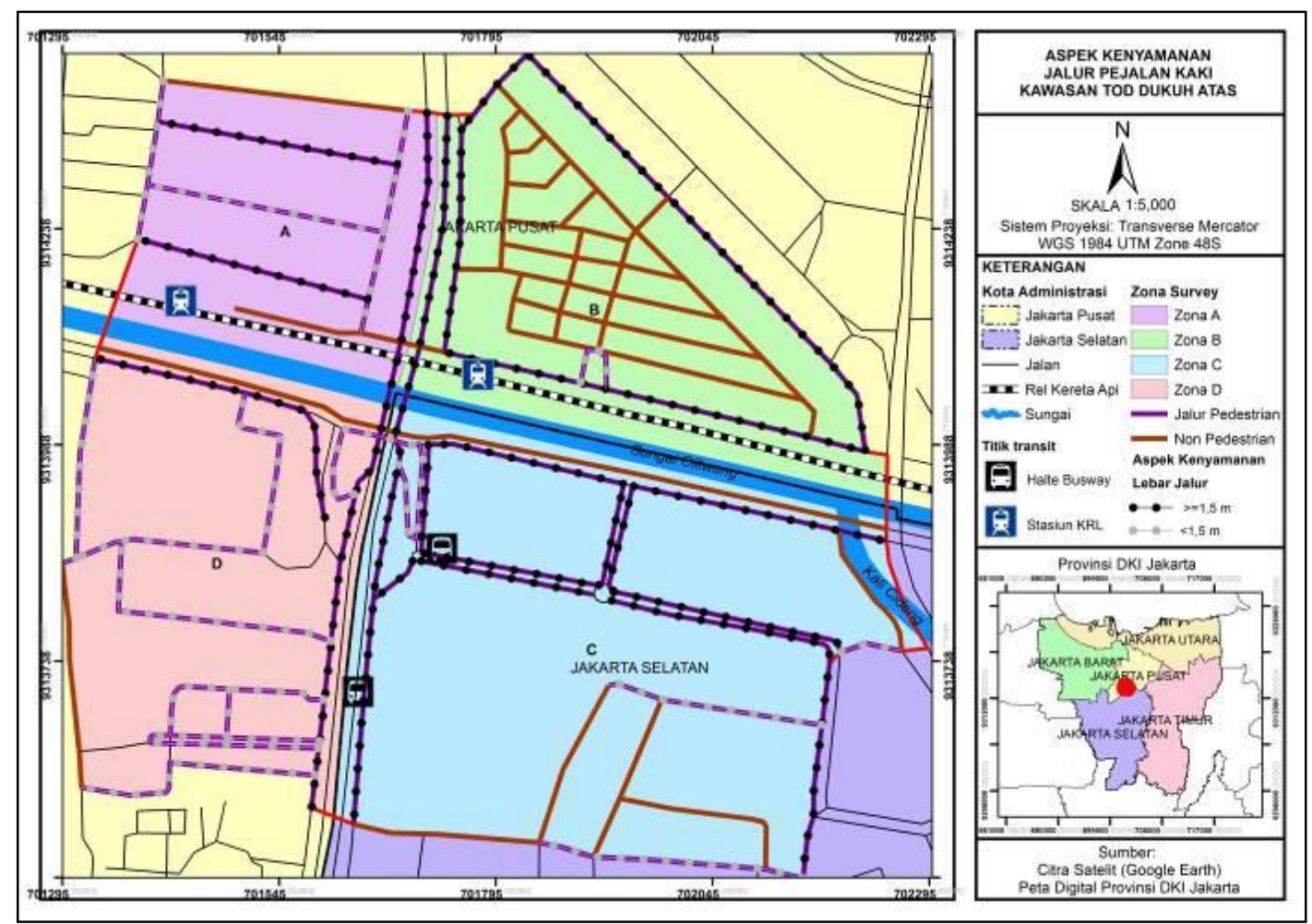

Gambar 7. Jalur Pejalan Kaki di Kawasan TOD Dukuh Atas.

Hasil penelitian di atas menunjukkan bahwa aspek kenyamanan pada jalur pejalan kaki di Kawasan Dukuh Atas telah memenuhi kriteria kesesuaian seperti yang tertuang dalam Permen 
PU No.3/PRT/M/2014 [7] terkait upaya akomodasi pergerakan penggunanya, khususnya di kawasan TOD.

3.3.3 Aspek aksesibilitas jalur pejalan kaki. Penilaian pada aspek aksesibiltas jalur pejalan kaki di Kawasan Dukuh Atas didasarkan pada empat kriteria, yaitu kemudahan pencapaian jalur, jalur yang menerus dan bebas dari halangan dan hambatan serta ketersediaan ramp yang tersebar secara merata untuk memudahkan pergerakan difabel. Tabel 6 di bawah ini menjelaskan skor kesesuaian pada aspek aksesibilitas.

Tabel 6. Skor kesesuaian aspek aksesibilitas jalur pejalan kaki di kawasan Dukuh Atas.

\begin{tabular}{|c|c|c|c|c|c|}
\hline \multicolumn{2}{|c|}{ Indikator } & \multirow{2}{*}{$\begin{array}{c}\text { Mean } \\
(\%)\end{array}$} & \multirow{2}{*}{ Ket. } & \multicolumn{2}{|c|}{ Skor } \\
\hline Sesuai & Tidak Sesuai & & & Sesuai & Tidak Sesuai \\
\hline $\begin{array}{l}\text { Mudah dicapai dari } \\
\text { muka blok }\end{array}$ & $\begin{array}{l}\text { Jalur pajalan kaki sulit } \\
\text { dicapai dari muka blok }\end{array}$ & 94 & & & \\
\hline $\begin{array}{l}\text { Tidak terhalang oleh } \\
\text { apapun }\end{array}$ & Terdapat penghalang & 63 & & & \\
\hline $\begin{array}{l}\text { Jalur pejalan kaki } \\
\text { menerus }\end{array}$ & $\begin{array}{l}\text { Jalur pejalan kaki } \\
\text { terputus }\end{array}$ & 96 & $\begin{array}{c}\text { Salah satu } \\
<50 \%=0\end{array}$ & 1 & 0 \\
\hline $\begin{array}{l}\text { Ketersediaan ramp } \\
\text { dengan derajat } \\
\text { kemiringan } \leq 7 \%\end{array}$ & $\begin{array}{l}\text { Tidak terdapat ramp } \\
\text { atau derajat } \\
\text { kemiringan }>7 \%\end{array}$ & 49 & & & \\
\hline
\end{tabular}

Menurut Tabel 6, ditemukan bahwa sebagian besar jalur pejalan kaki di Kawasan Dukuh Atas mudah dicapai dari muka blok dan memiliki pola yang menerus serta hanya sebagian kecil jalur yang ditemukan terhalang oleh sesuatu (lihat Gambar 8). Meskipun demikian, ketersediaan ramp untuk mengakomodasi pergerakan difabel tidak tersebar secara meratanya di seluruh jalur pedestrian yang ada, sehingga berpengaruh pada kesesuaian aspek aksesibilitas secara keseluruhan. Dengan demikian, dapat dikatakan bahwa jalur pejalan kaki di Kawasan TOD Dukuh Atas belum mampu mengakomodasi pergerakan penggunanya sesuai ketentuan yang tercantum dalam Permen PU No.3/PRT/M/2014 [7].

3.3.4 Aspek keindahan jalur pejalan kaki. Aspek keindahan pada jalur pedestrian di Kawasan Dukuh Atas ditinjau melalui pola dekoratif pada material penutup tanah sebagai nilai tambah pada ruang pergerakan pejalan kaki. Berikut ini adalah tabel skor kesesuaian pada aspek keindahan.

Tabel 7. Skor kesesuaian aspek keindahan jalur pejalan kaki di kawasan Dukuh Atas.

\begin{tabular}{|c|c|c|c|c|c|}
\hline \multicolumn{2}{|c|}{ Indikator } & \multirow{2}{*}{$\begin{array}{c}\text { Mean } \\
(\%)\end{array}$} & \multirow{2}{*}{ Ket. } & \multicolumn{2}{|c|}{ Skor } \\
\hline Sesuai & Tidak Sesuai & & & Sesuai & Tidak Sesuai \\
\hline $\begin{array}{l}\text { Terdapat pola } \\
\text { dekoratif pada } \\
\text { material penutup } \\
\text { tanah }\end{array}$ & $\begin{array}{l}\text { Material penutup } \\
\text { tanah hanya berpola } \\
\text { seperti jalur pejalan } \\
\text { kaki pada umumnya }\end{array}$ & 10 & $\geq 50 \%=1$ & 1 & 0 \\
\hline
\end{tabular}


Berdasarkan Tabel 7 dan Gambar 9, ditemukan bahwa jalur pejalan kaki yang memiliki pola dekoratif pada material pentutup tanah hanya terdapat di beberapa ruas saja dari total ruas jalur yang terdapat di Kawasan Dukuh Atas. Sehingga, dapat dikatakan aspek keindahan pada jalur pedestrian di kawasan penelitian tidak sesuai dengan konsep TOD menurut Permen PU No.3/PRT/M/2014 [7].

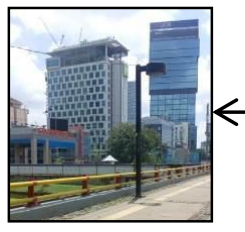

Jalur pedestrian sulit dicapai dari muka blok

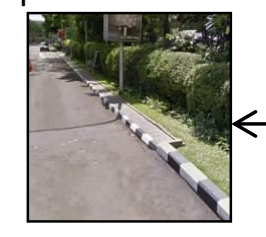

Jalur pedestrian terputus
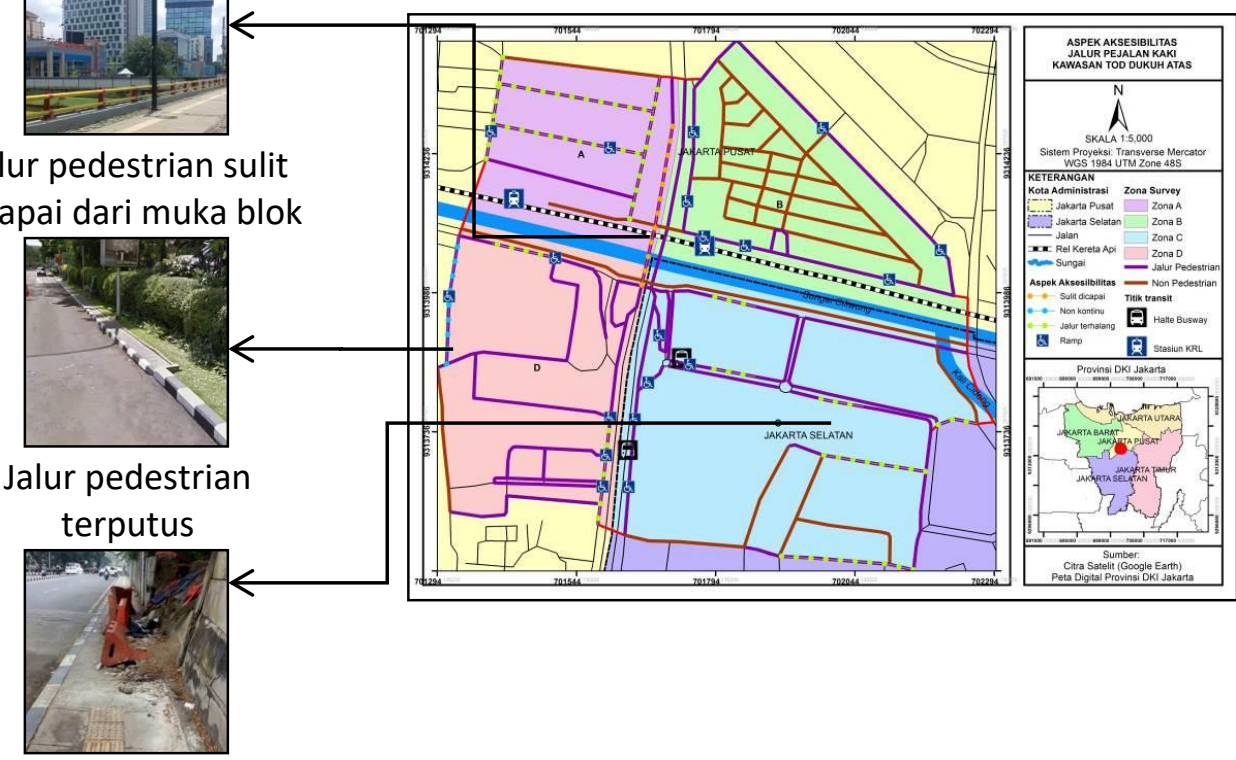

Terdapat halangan pada jalur pejalan kaki

Gambar 8. Aspek aksesibilitas jalur pejalan kaki di kawasan TOD Dukuh Atas.

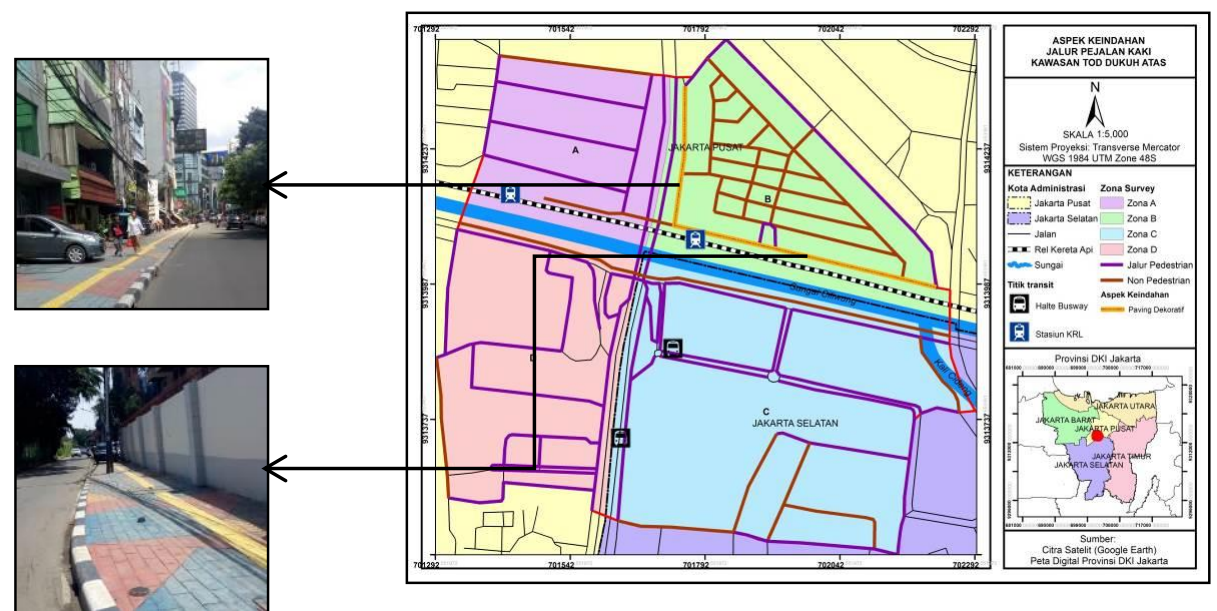

Pola dekoratif pada jalur pejalan kaki

Gambar 9. Aspek keindahan jalur pejalan kaki di kawasan TOD Dukuh Atas 
3.3.5 Aspek konektivitas jalur pejalan kaki. Aspek terakhir pada penilaian jalur pejalan kaki di Kawasan Dukuh Atas adalah aspek konektivitas yang terbagi ke dalam dua bagian yaitu konektivitas jalur dengan simpul transit dan konektivitas antar jalur. Berikut ini adalah tabel skor kesesuaian pada aspek konektivitas jalur pedestrian dengan simpul transit.

Tabel 8. Skor kesesuaian aspek konektivitas jalur pejalan kaki dengan simpul transit di kawasan Dukuh Atas.

\begin{tabular}{|c|c|c|c|c|c|}
\hline \multicolumn{2}{|c|}{ Indikator } & \multirow{2}{*}{$\begin{array}{c}\text { Mean } \\
(\%)\end{array}$} & \multirow{2}{*}{ Ket. } & \multicolumn{2}{|c|}{ Skor } \\
\hline Sesuai & Tidak Sesuai & & & Sesuai & Tidak Sesuai \\
\hline $\begin{array}{l}\text { Jalur pejalan kaki } \\
\text { tidak terputus } \\
\text { dengan akses masuk } \\
\text { ke simpul transit } \\
\text { (halte dan stasiun) }\end{array}$ & $\begin{array}{l}\text { Jalur pejalan kaki } \\
\text { terputus dengan akses } \\
\text { masuk ke simpul } \\
\text { transit (halte dan } \\
\text { stasiun) }\end{array}$ & 100 & $\geq 50 \%=1$ & 1 & 0 \\
\hline
\end{tabular}

Berdasarkan tabel 8 di atas, diketahui bahwa seluruh jalur pejalan kaki di Kawasan Dukuh Atas terhubung dengan halte bus Transjakarta dan stasiun kereta (lihat Gambar 4). Hal ini sesuai dengan konsep TOD dalam mengakomodasi pergerakan pejalan kaki yang juga merupakan pengguna moda transportasi umum massal menurut Permen PU No.3/PRT/M/2014 [7]. Selain dilihat dari keterhubungannya dengan simpul transit, aspek konektivitas jalur pejalan kaki di Kawasan Dukuh Atas juga ditinjau ketersediaan sarana penyeberangan yang menghubungkan antar jalur pedestrian. Berikut ini adalah tabel skor kesesuaian pada aspek tersebut.

Tabel 9. Skor kesesuaian aspek konektivitas antar jalur pejalan kaki di kawasan Dukuh Atas.

\begin{tabular}{|c|c|c|c|c|c|}
\hline \multicolumn{2}{|r|}{ Indikator } & \multirow{2}{*}{$\begin{array}{c}\text { Mean } \\
(\%)\end{array}$} & \multirow{2}{*}{ Ket. } & \multicolumn{2}{|c|}{ Skor } \\
\hline Sesuai & Tidak Sesuai & & & Sesuai & Tidak Sesuai \\
\hline $\begin{array}{l}\text { Tersedia sarana } \\
\text { penyebrangan }\end{array}$ & $\begin{array}{l}\text { Tidak terdapat sarana } \\
\text { penyeberangan }\end{array}$ & 51 & & & \\
\hline $\begin{array}{l}\text { Aksesibel untuk } \\
\text { difabel }\end{array}$ & $\begin{array}{l}\text { Sarana penyeberangan } \\
\text { tidak aksesibel untuk } \\
\text { difabel }\end{array}$ & 51 & $\begin{array}{l}\text { Salah satu } \\
<50 \%=0\end{array}$ & 1 & 0 \\
\hline
\end{tabular}

Keterangan: $1 / 0$ = skor yang diperoleh

Tabel 9 di atas menunjukkan bahwa jalur pejalan kaki di Kawasan Dukuh Atas saling terhubung satu sama lain dengan adanya sarana penyeberangan yang tersebar pada sebagian dari total ruas jalur pedestrian yang ada. Hal ini telah sesuai dengan ketentuan penyediaan sarana prasarana pejalan kaki di kawasan TOD yang tercantum dalam Permen PU No.3/PRT/M/2014 [7] (lihat Gambar 10). 


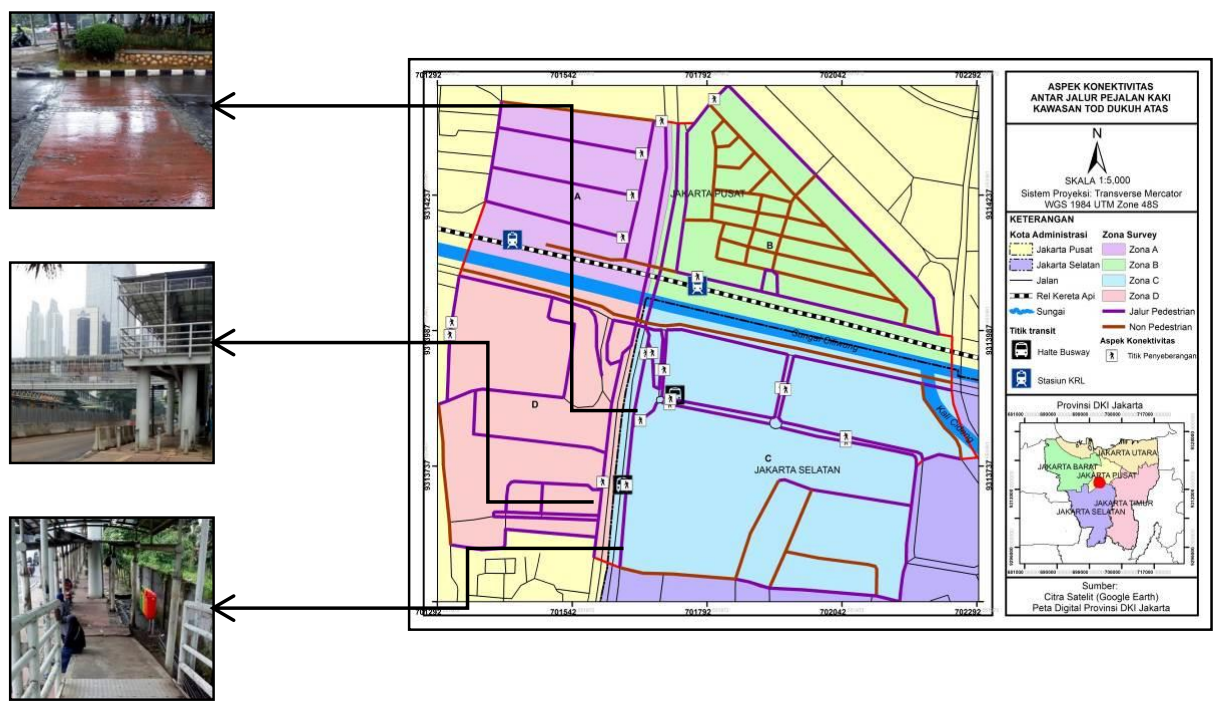

Persebaran sarana

penyeberangan di

Kawasan Dukuh Atas

Gambar 10. Aspek keterhubungan jalur pejalan kaki di kawasan TOD Dukuh Atas.

\subsection{Kesesuaian komponen fasilitas penunjang terhadap konsep TOD}

Penilaian kesesuaian pada komponen fasilitas penunjang ditinjau dari kelengkapan perabot jalan di sepanjang jalur pejalan kaki untuk memberikan rasa nyaman bagi penggunanya, desain perabot jalan untuk meningkatkan nilai estetika ruang dan ketersediaan tata informasi (signage) yang aksesibel bagi pejalan kaki. Berikut ini adalah tabel skor kesesuaian komponen fasilitas penunjang berdasarkan aspek-aspek penilaian tersebut.

Tabel 10. Skor kesesuaian komponen fasilitas penunjang.

\begin{tabular}{|c|c|c|c|c|c|c|}
\hline \multirow{2}{*}{ Parameter } & \multicolumn{2}{|c|}{ Indikator } & \multirow{2}{*}{$\begin{array}{c}\text { Mean } \\
(\%)\end{array}$} & \multirow{2}{*}{ Ket. } & \multicolumn{2}{|r|}{ Skor } \\
\hline & Sesuai & Tidak Sesuai & & & Sesuai & Tidak Sesuai \\
\hline $\begin{array}{l}\text { Kelengkapan } \\
\text { perabot jalan } \\
\text { pada jalur } \\
\text { pedestrian }\end{array}$ & $\begin{array}{l}\text { Terdapat jalur hijau } \\
\text { dengan vegetasi } \\
\text { peneduh untuk } \\
\text { pejalan kaki }\end{array}$ & $\begin{array}{l}\text { Tidak terdapat jalur } \\
\text { hijau atau vegetasi } \\
\text { peneduh }\end{array}$ & 33 & & & \\
\hline $\begin{array}{l}\text { untuk } \\
\text { memberikan } \\
\text { rasa nyaman } \\
\text { bagi pejalan }\end{array}$ & $\begin{array}{l}\text { Terdapat lampu } \\
\text { penerangan } \\
\text { Jarak antar lampu } 10 \\
\text { m }\end{array}$ & $\begin{array}{l}\text { Tidak terdapat } \\
\text { lampu penerangan } \\
\text { Jarak antar lampu } \\
\text { >10 m }\end{array}$ & $\begin{array}{l}100 \\
63\end{array}$ & $\begin{array}{l}\text { OI } \\
\text { ○े } \\
\text { ○ी }\end{array}$ & & \\
\hline kaki & $\begin{array}{l}\text { Terdapat tempat } \\
\text { duduk/bangku } \\
\text { Jarak antar bangku } \\
10 \mathrm{~m} \\
\text { Dimensi lebar 0,4-0,5 } \\
\text { m dan panjang } 1,5 \mathrm{~m} \\
\text { Terletak pada titik } \\
\text { yang mudah dicapai) }\end{array}$ & $\begin{array}{l}\text { Tidak tersedia } \\
\text { tempat duduk; } \\
\text { Jarak antar bangku } \\
\text { >10 m } \\
\text { Dimensi bangku } \\
\text { tidak sesuai standar } \\
\text { Tempat duduk } \\
\text { terletak di ruang } \\
\text { gerak pejalan kaki }\end{array}$ & $\begin{array}{l}10 \\
0\end{array}$ & 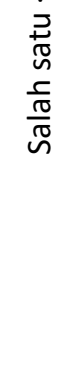 & 1 & 0 \\
\hline
\end{tabular}




\begin{tabular}{|c|c|c|c|c|c|c|}
\hline \multirow{3}{*}{ Parameter } & \multicolumn{2}{|c|}{ Indikator } & \multirow{2}{*}{$\begin{array}{c}\text { Mean } \\
(\%)\end{array}$} & \multirow{3}{*}{ Ket. } & \multicolumn{2}{|c|}{ Skor } \\
\hline & Sesuai & Tidak Sesuai & & & Sesuai & Tidak Sesuai \\
\hline & $\begin{array}{l}\text { Terdapat tempat } \\
\text { sampah } \\
\text { Jarak antar tempat } \\
\text { sampah } 20 \mathrm{~m} \\
\text { Terletak pada titik } \\
\text { yang mudah dicapai }\end{array}$ & $\begin{array}{l}\text { Tidak tersedia } \\
\text { tempat sampah } \\
\text { Jarak antar tempat } \\
\text { sampah >20 m } \\
\text { Tempat sampah } \\
\text { terletak di ruang } \\
\text { gerak pejalan kaki }\end{array}$ & 10 & & & \\
\hline $\begin{array}{l}\text { Desain perabot } \\
\text { jalan yang } \\
\text { meningkatkan } \\
\text { nilai estetika } \\
\text { ruang }\end{array}$ & $\begin{array}{l}\text { Karakter lokal mucul } \\
\text { pada desain street } \\
\text { furniture: } \\
\text { Lampu penerangan, } \\
\text { Tempat duduk atau } \\
\text { Tempat sampah }\end{array}$ & $\begin{array}{l}\text { Karakter lokal tidak } \\
\text { mucul pada desain } \\
\text { street furniture: } \\
\text { Lampu penerangan, } \\
\text { Tempat duduk atau } \\
\text { Tempat sampah }\end{array}$ & $\begin{array}{l}0 \\
0\end{array}$ & 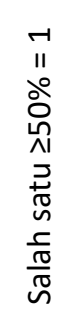 & 1 & 0 \\
\hline $\begin{array}{l}\text { Tata informasi } \\
\text { (signage) yang } \\
\text { aksesibel bagi } \\
\text { pejalan kaki }\end{array}$ & $\begin{array}{l}\text { Jalur pejalan kaki } \\
\text { dilengkapi rambu } \\
\text { dan marka jalan } \\
\text { (signage) } \\
\text { Signage terletak } \\
\text { pada titik/lokasi yang } \\
\text { mudah dilihat }\end{array}$ & $\begin{array}{l}\text { Jalur pejalan kaki } \\
\text { tidak dilengkapi } \\
\text { rambu dan marka } \\
\text { jalan (signage) } \\
\text { Signage terletak } \\
\text { pada titik/lokasi } \\
\text { yang sulit dilihat }\end{array}$ & 34 & 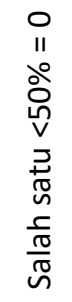 & 1 & 0 \\
\hline
\end{tabular}

Keterangan : $1 / 0$ = skor yang diperoleh

Berdasarkan Tabel 10 di atas, dapat diketahui bahwa masing-masing aspek penilaian pada komponen fasilitas penunjang tidak memenuhi kriteria kesesuaian dengan perolehan skor 0 . Dengan kata lain, komponen fasilitas penunjang yang tersedia di Kawasan Dukuh Atas tidak sesuai dengan konsep TOD dalam mengakomodasi pergerakan pejalan kaki. Hal tersebut berbanding tebalik dengan Dittmar dan Ohland [8], yang menyebutkan bahwa selain jalur pejalan kaki sebagai kebutuhan dasar, sarana prasarana penunjang juga dibutuhkan dalam mengakomodasi pergerakan pejalan kaki.

\subsection{Kesesuaian pelayanan pergerakan pejalan kaki terhadap konsep TOD di kawasan Dukuh Atas}

Rangkuman hasil analisis skoring pada masing-masing komponen TOD di Kawasan Dukuh Atas dapat dilihat pada Tabel 11. Berdasarkan Tabel 11, diketahui bahwa komponen yang memenuhi kriteria sesuai antara lain komponen kawasan kompak dan simpul transit. Pada komponen jalur pejalan kaki, terdapat tiga aspek yang sesuai dengan kriteria yaitu aspek kenyamanan dan aspek konektivitas jalur, baik dengan simpul transit maupun antar jalur. Sedangkan, komponen fasilitas penunjang tidak memenuhi kriteria sesuai pada masingmasing aspek penilaian. Dengan mengacu pada total skor di atas, nilai kesesuaian yang didapat adalah sebesar $53,8 \%$. Hasil tersebut mengindikasikan bahwa pelayanan pergerakan pejalan kaki yang tersedia di Kawasan Dukuh Atas sesuai dengan konsep TOD. 
Tabel 11. Skor kesesuaian tiap komponen.

\begin{tabular}{llc}
\hline \multicolumn{1}{c}{ Variabel } & \multicolumn{1}{c}{ Parameter } & Skor \\
\hline Kawasan & Kawasan campuran padat bangunan yang saling terkoneksi dengan jalur & 2 \\
Kompak & $\begin{array}{l}\text { pejalan kaki } \\
\text { Kawasan terintegrasi dengan simpul transit }\end{array}$ & 2 \\
Transul & Simpul transit terjangkau dengan berjalan kaki & Simpul transit aksesibel bagi pejalan kaki \\
Jalur Pejalan & Jalur pejalan kaki yang aman \\
Kaki & Jalur pejalan kaki yang nyaman \\
& Jalur pejalan kaki yang aksesibel (khususnya bagi difabel) \\
& Pola dekoratif pada jalur pejalan kaki & 3 \\
& Jalur pejalan kaki terhubung dengan simpul transportasi (integrasi) & \\
Kasilitas & Keterhubungan prasarana pejalan kaki yang berseberangan \\
Penunjang & nelengkapan perabot jalan pada jalur pedestrian untuk memberikan rasa & \\
& Desain perabot jalan yang meningkatkan nilai estetika ruang & \\
& Tata informasi (signage) yang aksesibel bagi pejalan kaki & \\
& & \multicolumn{1}{c}{ Total Skor } \\
\hline
\end{tabular}

\section{Kesimpulan}

Berdasarkan penjabaran hasil penelitian, diketahui bahwa nilai kesesuaian yang diperoleh adalah sebesar $53,8 \%$. Dengan hasil tersebut, pelayanan pergerakan pejalan kaki di Kawasan Dukuh Atas termasuk ke dalam kelas 'sesuai' dengan konsep TOD. Diketahui pula, masih terdapat beberapa aspek yang belum sesuai dengan standar yang ditetapkan pada sebuah kawasan berkonsep TOD. Untuk itu, diperlukan adanya upaya peningkatan kualitas pada masing-masing aspek agar jalur pejalan kaki di kawasan TOD Dukuh Atas dapat mengakomodasi pergerakan penggunanya secara optimal.

\section{Referensi}

[1] Calthorpe P 1993 The Next American Metropolis: Ecology, Community, and the American Dream (Canada: Princeton Architectural Press)

[2] Institute for Transportation and Development Policy 2017 TOD Standard New York: Despacio Diakses dari www.itdp.org

[3] City of Fort Collins 2011 Fort Collins Pedestrian Plan Diakses dari http://www.pedbikeinfo.org/

[4] Delhi Development Authority 2012 Transit Oriented Development: Policy, Norms, Guidelines

Diakses

dari https://smartnet.niua.org/sites/default/files/resources/5320760375.pdf

[5] Pemerintah Provinsi DKI Jakarta 2012 Peraturan Daerah Gubernur DKI Jakarta Nomor 1 Tahun 2012 tentang Rencana Tata Ruang dan Wilayah DKI Jakarta 2011-2030 Indonesia Diakses dari http://pelayanan.jakarta.go.id/download/regulasi/peraturandaerah-nomor-1-tahun-2012-tentang-rencana-tata-ruang-wilayah-2030.pdf 
[6] Mauliani L, Purwantiasning A W, dan Aqli W 2015 Designing Better Environment by Providing Pedestrian Way for Pedestrian Procedia - Social and Behavioral Sciences 179 80-93 DOI: 10.1016/i.sbspro.2015.02.412

[7] Kementerian Pekerjaan Umum Republik Indonesia 2014 Peraturan Menteri Pekerjaan Umum Republik Indonesia Nomor 03/PRT/M/2014 tentang Pedoman Perencanaan, Penyediaan, dan Pemanfaatan Prasarana dan Sarana Jaringan Pejalan Kaki di Kawasan Perkotaan Indonesia Diakses dari http://pugpupr.pu.go.id/ uploads/Produk Pengaturan/Permen\%20PUPR\%20No\%20032014.pdf

[8] Dittmar H dan Ohland G 2004 The New Transit Town - Best Practices in Transit Oriented Development (Washington DC: Island Press) 